\title{
Microwave Technology for Waste Management Applications: Treatment of Discarded Electronic Circuitry (U)
}

by

\author{
G. G. Wicks
}

Westinghouse Savannah River Company

Savannah River Site

Aiken, South Carolina 29808

D. E. Clark

University of Florida

FL USA

R. L. Schulz

University of Florida

FL USA

This paper was prepared in connection with work done under the above contract number with the U.S.

Department of Energy. By acceptance of this paper, the publisher and/or recipient acknowledges the U. S. Government's right to retain a nonexclusive, royalty-free license in and to any copyright covering this paper, along with the right to reproduce and to authorize others to reproduce all or part of the copvrighted papaer. 


\section{DISCLATMER}

This report was prepared as an account of work sponsored by an agency of the United States Government. Neither the United States Government nor any agency thereof, nor any of their employees, makes any warranty, express or implied, or assumes any legal liability or responsibility for the accuracy, completeness, or usefulness of any information, apparatus, product, or process disclosed, or represents that its use would not infringe privately owned rights. Reference herein to any specific commercial product, process, or service by trade name, trademark, manufacturer, or otherwise does not necessarily constitute or imply its endorsement, recommendation, or favoring by the United States Government or any agency thereof. The views and opinions of authors expressed herein do not necessarily state or reflect those of the United States Government or any agency thereof.

This report has been reproduced directly from the best available copy.

Available to DOE and DOE contractors from the Office of Scientific and Technical Information, P.O. Box 62, Oak Ridge, TN 37831; prices available from (615) 57.6-8401.

Available to the public from the. National Technical.Information Service, U.S. Department of Commerce, 5285 Port Royal Road, Springfield, VA. 22161. 


\title{
MICROWAVE TECHNOLOGY FOR WASTE MANAGEMENT APPLICATIONS: TREATMENT OF DISCARDED ELECTRONIC CIRCUITRY
}

G.G. Wicks, Westinghouse Savannah River Technology Center, Aiken, SC

D.E. Clark and R.L. Schulz, University of Florida, Gainesville, FL

\begin{abstract}
Significant quantities of hazardous wastes are generated from a multitude of processes and products in today's society. This waste inventory is not only very large and diverse, but is also growing at an alarming rate. In order to minimize the dangers presented by constituents in these wastes, microwave technologies are being investigated to render harmless the hazardous components and ultimately, to minimize their impact to individuals and the surrounding environment.

\section{INTRODUCTION}

Microwave technology is being developed world-wide as part of an environmental remediation arsenal. Current efforts include treatment and destruction of various gaseous, liquid and solid hazardous wastes as well as subsequent immobilization of hazardous species into highly durable glass matrices. This paper will emphasize the use of microwave energy for treatment of discarded electronic circuitry and subsequently, reclamation of the important metals contained within. Also, a new Hybrid Microwave Treatment Center, now being proposed at the Savannah River Site for remediation studies of a variety of wastes, will be discussed.
\end{abstract}


Hybrid microwave treatment of potentially hazardous materials and components is being actively examined jointly by the Westinghouse Savannah River Technology Center (WSRC) and the University of Florida (UF). One program of special interest is the destruction and vitrification of electronic components and recovery of precious metals for reuse. Important advantages of this technology include (a) simplicity of operation, (b) significant waste volume reduction, and $\mathbb{C}$ production and separation of metal and waste glass forms. Vitreous forms are known to be especialiy effective matrices for immobilization of hazardous and radioactive wastes $[1,2]$. The waste glass product produced using microwave energy was found to immobilize electronic hazardous components into glass products that meet environmental leaching standards. The metal product formed allowed precious and other metals to be conveniently reclaimed for recycling. The waste glass forms have also been successfully produced without the need of any additives.

\section{POTENTIAL ADVANTAGES}

Microwave processing of potentially hazardous wastes can result in many important advantages to waste form producers. The potential advantages of using microwave energy for waste remediation can include some or all of the following features:

- Waste volume reduction

- High temperature capabilities

- Enhanced chemical reactivity

- Ease of control

- Portability of equipment

- Treatment or immobilization of hazardous components to meet regulatory requirements for storage, transportation or disposal

- Rapid and flexible process that can also be made remote

- Process equipment availability, compactness, cost, maintainability

- Reduction in personnel radiation exposure for rad wastes

- Cleaner energy source compared to some more conventional systems

The advantages to be realized depend on many factors, especially the type and characteristics of the wastes or conditions to be treated. 


\section{WASTE CANDIDATES FOR MICROWAVE TREATMENT}

There are many types of hazardous wastes that are candidates for microwave treatment and are discussed in a number of fine overviews [3-8]. Wastes currently under study and of special interest include radioactive wastes and sludges (high, low, and intermediate level wastes, transuranic and mixed wastes), contaminated soils and sediments, incinerator ashes, industrial wastes and sludges, medical and infectious wastes, asbestos, groundwaters, volatile organic compounds (VOC's), and discarded electronic circuitry. Treatment of these various wastes tell us a great deal about the advantages of using microwave energy and the applicability of these potential new markets for the future.

\section{DESTRUCTION OF ELECTRONIC CIRCUITRY AND RECLAMATION OF PRECIOUS METALS}

Electronic components and circuits are indispensable parts of our society today and are vital components in a multitude of consumer products and services. Each year, many of these products containing electronic circuitry are retired (see Figure 1). Hence, millions and millions of electronic components and circuit boards must be disposed of in a cost effective and environmentally safe manner. At present, many consumer products containing electronic components are discarded in landfills throughout our nation. This results in a number of concerns. First, because of the very large volume of these materials, many landfills are now filling up, resulting in the need for new disposal sites and increased costs to all. Next, there are a variety of hazardous materials found in electronic components. In landfills, these elements can leach from the waste and make their way into groundwaters, which can result in undesirable public and environmental consequences. Finally, because the products are simply thrown away, there is no attempt to reclaim useful materials within the circuits and hence, natural resources in these wastes, including precious metals, are discarded and cannot be reused or recycled.

Laboratory-scale experiments on treatment and disposition of electronic circuitry, have produced the following results:

- A variety of electronic components were successfully treated by a relatively simple, 1-step, hybrid-heated microwave process 


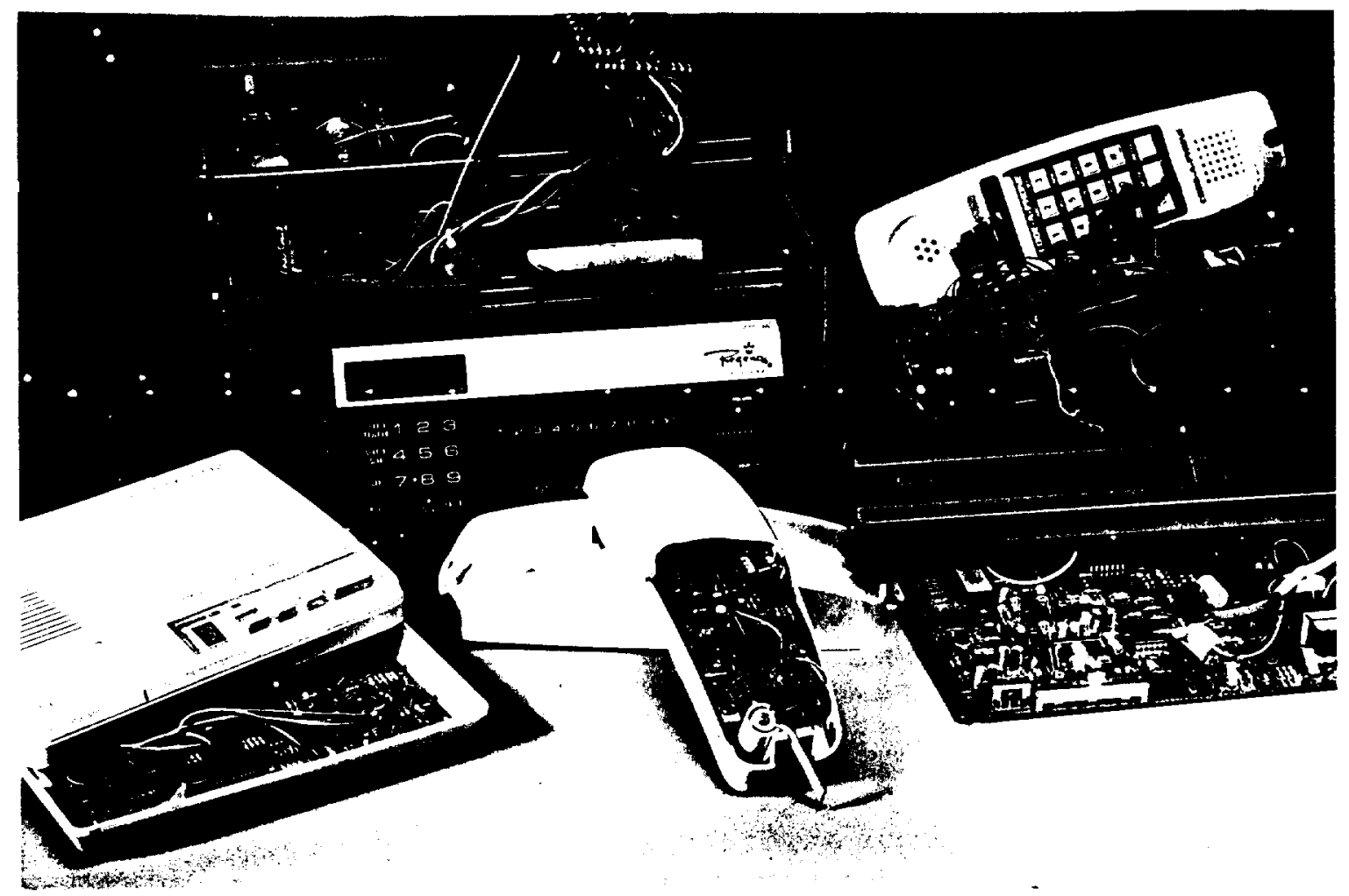

Figure 1. Representative sources for discarded electronic circuitry.

- Actual waste volume reductions greater than $50 \%$ were achieved while geometric volume reductions were significantly greater

- As a result of the controlled microwave treatment process, important metal components were readily separated from waste glass

- A waste glass product was able to be fabricated without the use of any additives and the glass produced retained hazardous components which met environmental leaching standards

- Precious metals, including gold and silver, were separated effectively and reclaimed for reuse

These results have been documented elsewhere [9-14] and are summarized in Figures 2 and 3. 


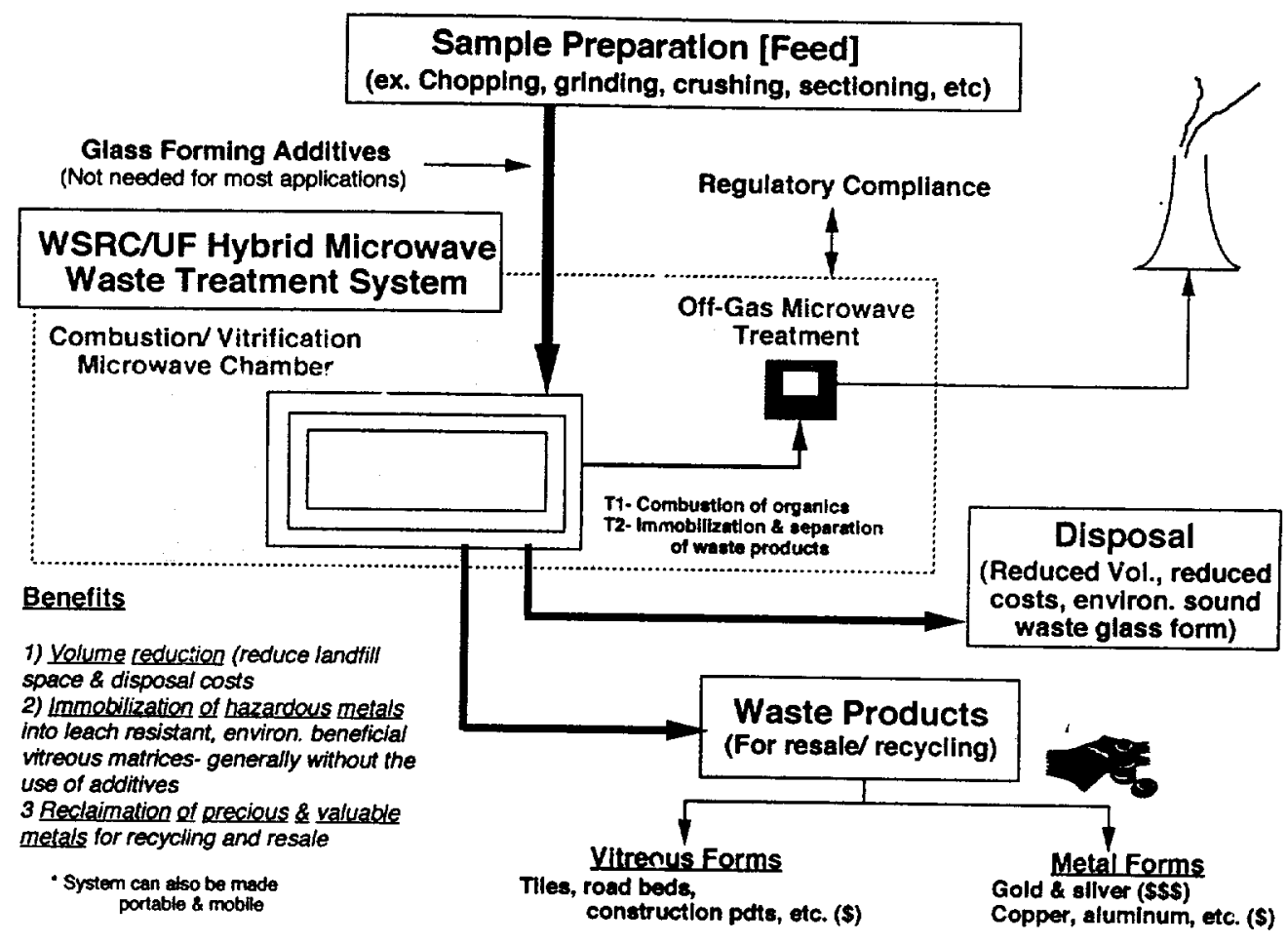

Figure 2. Flowchart showing overview of processing steps involved in the microwave treatment of waste circuit boards.

Microwave studies have been applied not only to treatment of the primary waste streams, but also to treatment of the secondary wastes produced, i.e., offgases, using a new tandem microwave treatment concept shown in Figure 4. This technology is currently being patented jointly by WSRC and UF. The process consists of removal of organics in the microwave combustion chamber (lower unit) while simultaneously treating the resulting emissions by passing them through a series of heated filters $\left(\sim 1000^{\circ} \mathrm{C}\right)$ in the upper microwave chamber. Gas chromatography data have shown that the amount of hazardous components found in the off gases are substantially reduced by this microwave treatment (Table 1). While only laboratory scale studies have been performed to date, it is believed that the overall concept and process can be scaled-up 


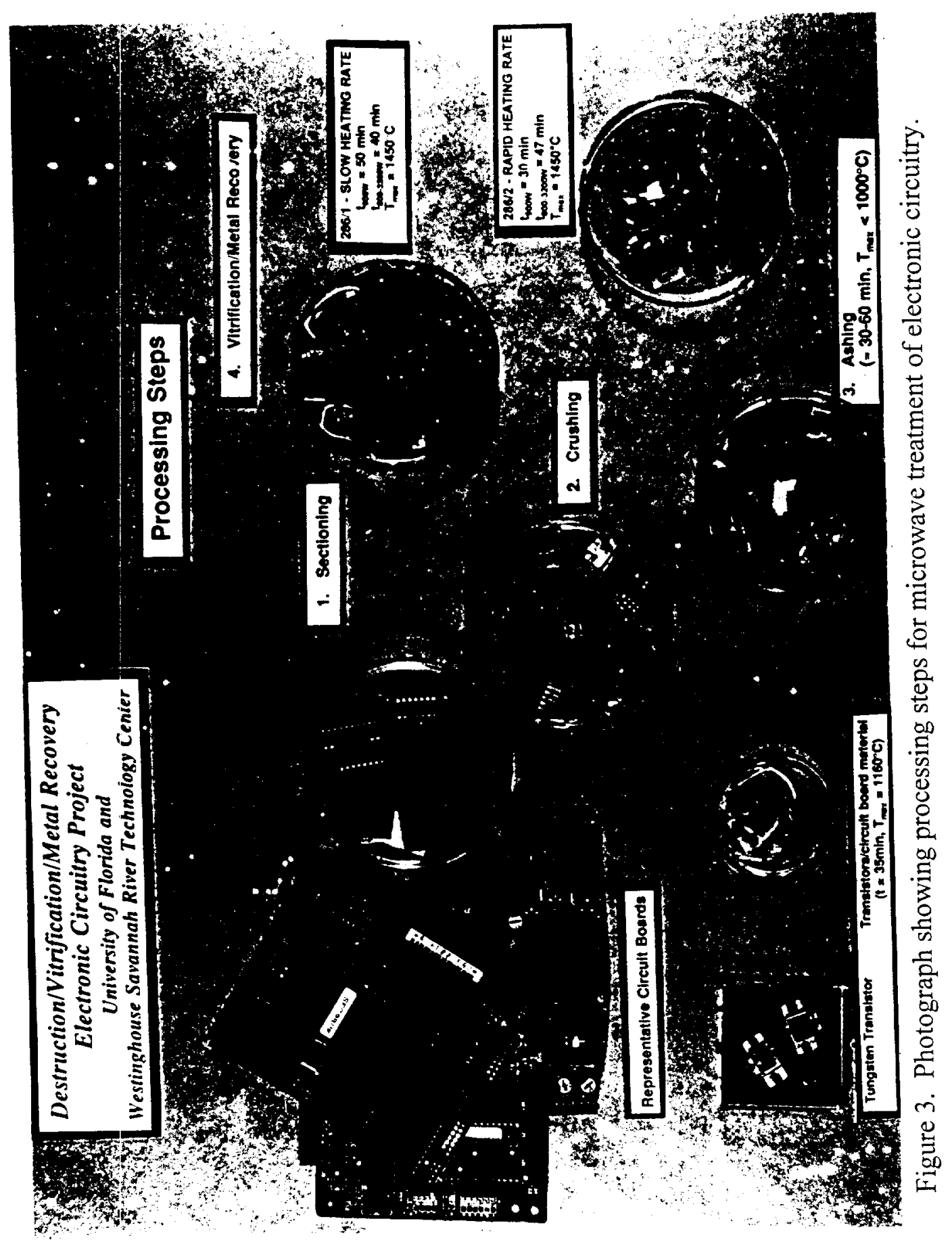




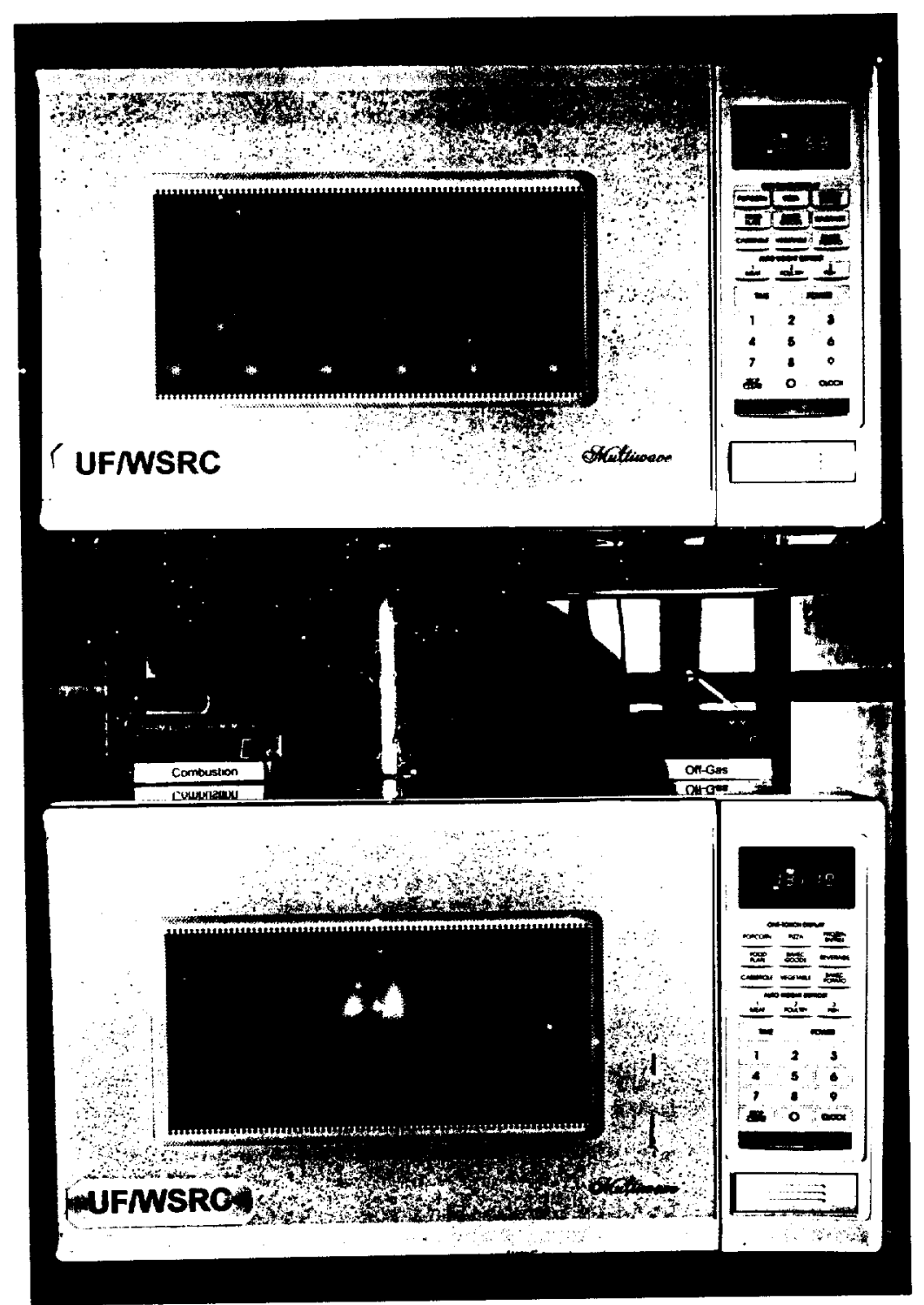

Figure 4. Photograph of tandem microwave waste treatment system.

to production levels and be made mobile, if desired. A new Hybrid Microwave Treatment Center, proposed for the Savannah River Site, will evaluate scaling up of this technology and its ultimate commercial viability. 
Table 1. Preliminary Gas Chromatography Data Collected Before and After Microwave Treatment of Emissions Resulting From the Combustion of Unreinforced Circuit Boards (modified tandem microwave system).

\begin{tabular}{|l|l|l|l|l|}
\hline \multirow{2}{*}{ COMPOUND } & \multicolumn{3}{|c|}{ SR-8 EMISSIONS (ng) } & \multicolumn{2}{|c|}{ SR-9 EMISSIONS (ng) } \\
& \multicolumn{1}{|c|}{ A } & \multicolumn{1}{c|}{ A } & \multicolumn{1}{c|}{ B } \\
\hline Benzene* & 5838.9 & $\mathbf{2 2 . 2}$ & 1415.6 & $\mathbf{1 3 9 . 5}$ \\
\hline Toluene* & 8146.6 & $\mathbf{1 5 . 7}$ & 4215.9 & $\mathbf{1 5 8 . 7}$ \\
\hline Ethylbenzene* & 1147.4 & nd & 4557.0 & $\mathbf{5 . 2}$ \\
\hline Styrene* & 1666.9 & $\mathbf{6 . 2}$ & 20012.0 & $\mathbf{3 8 . 4}$ \\
\hline Naphthalene* & 355.5 & nd & 2403.6 & $\mathbf{2 7 . 9}$ \\
\hline m/p Xylene* & 2259.0 & nd & 510.6 & nd \\
\hline $1,3,5$ Trimethylbenzene & 1564.0 & nd & 378.7 & $\mathbf{6 4 . 3}$ \\
\hline $1,2,4$ Trimethylbenzene & 904.7 & nd & 171.8 & nd \\
\hline
\end{tabular}

$A=$ before microwave off-gas treatment; $B=$ after microwave off-gas treatment *Listed in the Clean Air Act (as amended, 1990) as hazardous air pollutants.

\section{HYBRID MICROWAVE TREATMENT CENTER'AT SRS}

\section{Project Mission}

A proposal has been developed by a the Westinghouse Savannah River Company to establish an interdisciplinary, multi-organizational team for the purpose of conducting a demonstration project using hybrid microwave technology for waste remediation applications. The focus of the project is to scale up the successful laboratory research and development work. The emphasis of the effort will be on treatment of discarded electronic components within the Department of Energy, the 
Department of Defense and the commercial sector. Objectives include evaluation of the feasibility, technical merits, costs, and environmental benefits of the technology on a larger scale, and development of a commercialization path forward. Direct benefits of this effort to customers include: reduced use of landfill space and thus reduced waste management costs, immobilization of hazardous materials, reclamation of reusable metals and, compliance with international trade "take-back" policies.

\section{Industrial Partnering for a Variety of Specialized Waste Management Applications}

The Hybrid Microwave Treatment Center is designed to be a unique, multipurpose research facility to allow industrial partners to examine tailored microwave technology for their individual needs, in both a time efficient and cost effective manner. The team has been approached by several companies for a variety of different potential applications, only a few of which are currently being pursued, due to existing resources. The new Hybrid Microwave Treatment Center is designed to be a versatile facility and to provide unique capabilities that can be leveraged upon. For example, additional tailored microwave units can be readily integrated into the proposed microwave system, which can also utilize a common, extensive off-gas system. Therefore, a resource is provided to potential customers in which microwave technology can be examined for their specific needs by only incremental costs in equipment, operations and personnel. Further information, including technology briefs describing in more detail this technology, potential applications and the proposed Hybrid Microwave Treatment Center, are avajlable upon request.

\section{SUMMARY}

There are many potential advantages of using microwave energy for remediation of a wide range of hazardous materials. This technology can provide an important contribution to an already existing and growing arsenal of remediation tools. In order to more fully assess the technical merits of this technology on a commercial scale, demonstration projects are needed involving all key participants, including technology experts and governmental and industrial customers, for the services or products produced. 
A Hybrid Microwave Treatment Center at the Savannah River Site, involving many interested parties, has been proposed to assess microwave waste remediation technology that has been developed jointly by a federal site and academia. The Center is designed to be flexible and leverage important resources including buildings, equipment and personnel. The Center is designed to carry out a primary mission of microwave treatment of electronic circuitry and reclamation of precious metals, and to also allow other potential microwave waste treatment applications to be examined by industrial partners.

\section{REFERENCES}

1. Wicks, G.G., "Nuclear Waste Glasses," Treatise on Materials Science and Technology, Glass IV, M. Tomozawa and R.H. Doremus, eds., Vol. 26, pp. 57-118 Academic Press, Inc. (1985).

2. U.S. Environmental Protection Agency, Handbook- Vitrification Technology for Treatment of Hazardous and Radioactive Waste, EPA/625/R-92/002 (1992).

3. Oda, S.J., "Microwave Remediation of Hazardous Waste: A Review," Microwave Processing of Materials III, (R.L. Beatty, W.H. Sutton and M.F. Iskander, eds.), Materials Research Society, Vol. 269, pp. 453-464 (1992).

4. Dauerman, L., Windgasse, G., Zhu, N. and He, Y., "Microwave Treatment of Hazardous Wastes: Physical Chemical Mechanisms," Microwave Processing of Materials III, (R.L. Beatty, W.H. Sutton and M.F. Iskander, eds.), Materials Research Society, Vol. 269, pp.465-469 (1992).

5. Krause, R.T. and Helt, J.E., "Applications of Microtwave Radiation in Environmental Remediation Technologies," Microwaves: Theory and Application in Materials Processing II, Ceramic Transactions (D.E. Clark, W.R. Tinga and J.R. Laia, eds.), American Ceramic Society, Vol. 36, pp. 5359 (1993).

6. Oda, S.J., "Microwave Applications to Process Nuclear and Hazardous Waste", Microwaves: Theory and Application in Materials Processing II, Ceramic Transactions (D.E. Clark, W.R. Tinga and J.R. Laia, eds.), American Ceramic Society, Vol. 36, pp. 73-79 (1993).

7. Oda, S.J., "Dielectric Processing of Hazardous Materials- Present and Future Opportunities," Microwave Processing of Materials IV, (M.F. Iskander, R.J. Lauf and R.L. Beatty, eds.), Materials Research Society, Vol. 347, pp. 371-382 (1994). 
8. Wicks, G.G., Clark, D.E., Schulz, R.L. and Folz, D.C., "Microwave Technology for Waste Management Applications Including Disposition of Electronic Circuitry," Microwaves: Theory \& Application in Materials Processing III, Ceramic Trans, (D.E. Clark, D.C. Folz, S.J. Oda and R. Silberglitt, eds.), Vol. 59, pp. 79-89 (1995).

9. Schulz, R.L., Fathi, Z., Clark, D.E., and Wicks G.G., "Microwave Processing of Simulated Nuclear Waste Glass," presented at the Symposium on Microwaves: Theory and Application in Materials Processing, April 28- May 2, 1991, Cinn. OH, Ceramic Transactions, iNuclear Waste Management IV (G.G. Wicks, D.F. Bickford and L.R. Bunnell, eds.), Vol. 23, pp. 779- 786 (1991).

10. Schulz, R.L., Clark, D.E., Hutcheon, R.M. and Wicks, G.G., "Microwave Processing of Simulated Nuclear Waste Glass II," Microwaves: Theory and Application in Materials Processing II, Ceramic Transactions (D.E. Clark, W.R. Tinga and J.R. Laia, eds.), American Ceramic Society, Vol. 36, pp. $89-97$ (1993).

11. Schulz, R.L., Folz, D.C., Clark, D.E. and Wicks, G.G., "Microwave Destruction/ Vitrification of Electronic Components," Microwaves: Theory and Application in Materials Processing II, Ceramic Transactions (D.E. Clark, W.R. Tinga and J.R. Laia, eds.), American Ceramic Society, Vol. 36, pp. 81-88 (1993).

12. Schulz, R.L., Folz, D.C., Clark, D.E., and Wicks, G.G., "Microwave Energy for Waste Remediation Applications", Microwave Processing of Materials IV, (M.F. Iskander, ed.), Materials Research Society Symposium Proceedings, Vol. 347, pp. 401-406 (1994).

13. Schulz, R.L., Folz, D.C., Clark, D.E., Schmidt, C.J. and Wicks, G.G., "Microwave Treatment of Emissions from the Destruction of Electronic Circuitry," Microwaves: Theory \& Application in Materials Processing III, Ceramic Transactions, D.E. Clark, D.C. Folz, S.J. Oda and R. Silberglitt, eds., Vol. 59, pp. 107-114 (1995).

14. Schulz, R.L., Folz, D.C., Clark, D.E., Schmidt, C.J. and Wicks, G.G., "Microwave Waste Treatment System," poster presentation at the First World Congress on Microwave Processing, Lake Buena Vista, FL, Jan. 5-9 (1997). 


\section{Tite}

Microwave Technology for Waste Management Applicatlons; Treatment of Electronlc Circultry (U)

Primary Author/Contact (Must be WSRC)

G.G. Wicks (WSRC)

Organization Code

\begin{tabular}{|l|l|}
\hline $\begin{array}{l}\text { Location } \\
773 A, B-129\end{array}$ & $\begin{array}{c}\text { Phone No. } \\
5-3190\end{array}$ \\
\hline $\begin{array}{l}\text { Organization (No Abbreviations) } \\
\text { Focus Area Programs }\end{array}$
\end{tabular}

Focus Area Programs

L0200

Other Authors

Prof. D.E. Clark and R.L. Schulz (University of Florida)

Has an invention disclosure been submitted related to this information? $\triangle$ Yes $\square$ No

Disclosure No. (If Known) SRS-92-108

Title Microwave Vitrif. of Mat's.

\begin{tabular}{|l|c|}
\hline Position & User ID \\
Sr. Advisory Scientist & T-3869 \\
\hline
\end{tabular}

Do you intend to submit an invention disclosure? $\square$ Yes $\square$ No If yes, projected date

\begin{tabular}{|l|l} 
Information Product Description & Conlerence Meeting Presentation
\end{tabular}

$\square$ Report Type

$\square$ Quarterly $\square$ Annual $\square$ Final $\square$ Other

$\square$ Semiannual $\square$ Technical $\square$ Topical

Report Dates_ thru

$\square$ Conference Type
$\square$ Abstract
$\square$ Conf Paper
$\square$ Published Proceedings

$\square$ Slides

$\otimes$ Joumal Article (Joumal Name) Advances in Ceramics

$\square$ Videotape/Multimedia

$\square$ External Web Page

$\square$ Software (Additional forms are required (ESTSC F1 and F2)).

\section{References $\triangle$ In Public Literature $\square$ Routing Concurrently}

$\square$ Approved for Rolease $\square$ Other

Meoting Tits (No Abbreviations)

Meeting Address (City, State, Country)

Deadline Date for Approval

$5 / 1 / 97$

Date Submitted 1/15/92

I understand that for the information in this material to be given external disbribution, approvals by both WSRC and, as appropriate, DOE-SR are required. Distribution (verbally or published) must be-in accordance Fip policies set forth in WSAC management requirements and procedures (MAP 3.25) and in DOE-SR orders, and the content of the exiernal distributiby muss bi dini to that actually approved.

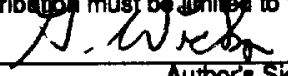

Author's Organization

Approvals by Author

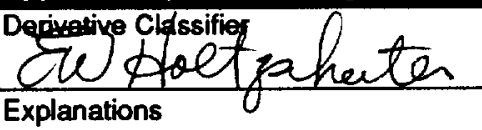

$(m / d / y)$ thru $(\mathrm{m} / \mathrm{d} / \mathrm{y})$

I understand and have considered whether any potential intellectual property rights (palents, copyrights, etc., in accordance with MP 1.09 and MRP 1.07) or any contractural barriers (CRADAs, Work for Others, etc.) may be involved belore authorizing that this document be proposed for public release. If any concerns were identified, these have been discussed and resolved with General Counsel.

$$
\frac{E \omega \text { to l fischei tey }}{\text { Manager's tame (Print) }}
$$

Classification

U

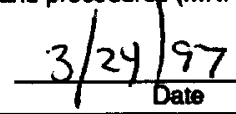

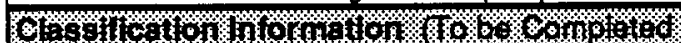

$\begin{array}{lllll}\text { Classification (Check One for Each) } & & \\ \text { Overall } & \square \text { s } & \square c & \square \text { UCNI } \\ \text { Abstract } & \square \text { s } & \square c & \square \text { uCNI } \\ \text { Tite } & \square \text { s } & \square \text { c } & \square \text { UCNI } & \square \text { U }\end{array}$

WSRC Classification Officer's Name (Print)

T-R. Coughenour

Eu thetrochets

Mantogr's Signature

Distribution

区unlimited $\square$ Limited (Explain Below)

of Classification Officor's

$\frac{3-2497}{\text { Date }}$

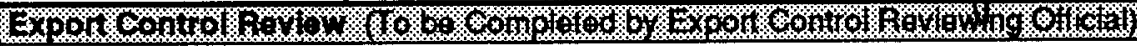

Export Control Rolated

$\square$ Yes Ino $_{\text {No }}$

Export Control Reviewer's Name (Print)

T.R. COughonelR

Classification Guide Topics

\begin{tabular}{c|c} 
UC/C Number & Routing \\
705 & Class/E C D DOE
\end{tabular}

Export Control Roviewer's Signature

(3). Coybrin

Date
$3 / 36 / 97$

STIFrogram Use OnV

NOTE OSP 17-8 must be completed in addition to this form when submitting information for review and approval. 


\section{U.S. DEPARTMENT OF ENERGY

\section{PART I Information Product Identification}

\section{A. Identifiers}

1. Product/Report Nos.

WSRC-MS-97-0299

3. Title
2. Award/Contract Nos.

DE-AC09-96SR18500

Microwave Technology for Waste Management Applications: Treatment of Discarded Electronic Circuitry (U)

(Grantees and Awardees skip to Part 1.B.)
4. Funding Office(s)
5. B\&R Code(s)
6. Project ID(s)

DOE-SR

7. CRADA Nos.

8. UC/C Category(ies)

UC-705

B. Information Product Description

1. Report

a. Type

Quarterly

Semiannual

Annual

Final

Topical

Other (Specify)

b. Dates covered ( $m m / d d / y y y y)$

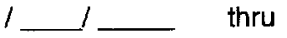

'

2. Conference

a. Type

Conference paper

Published proceedings

Other (Specify)

b. Conference title (No abbreviations) -

c. Conference location (city/state/country)

d. Conference dates ( $m m / d d / y y y)$

thru

e. Conference sponsor(s)

3. Software (Note: Additional forms are required. Follow instructions provided with this form.)

4. Other (Provide complete description.) 


\section{Information Product Format}

1. Product not submitted to OSTI (i.e., electronic version)

a. Location (FTP, URL, etc.)

b. File format SGML Postscript __ PDF TIFFG4 Other (Specify)

c. SGML bibliographic record available With product Separately (Specify)

2. Product submitted to OSTI (i.e., electronic, paper, audiovisual, or computer medium)

a. Number of copies
$\checkmark$ (1) Two for unclassified processing
(2) _ copies for program unclassified distribution
_ (3) One for classified processing
(4) ___ copies for standard classified distribution
(5) ___ copies for OSTI to reproduce (Complete part C.3.)
(6) Other (Complete part C.3.)

b. SGML bibliographic record submitted to OSTI With product Separately (Specify)

c. Method of transmittal to OSTI

(1) Electronic (e.g., FTP, E-mail) (Note: Transmit only unclassified unlimited information not subject to access limitations over open systems. Contact OSTI for further information.)
(a) File format
SGML
HTML Postscript PDF TIFFG4 Other (Specify)

(2) Computer medium (e.g., magnetic tape or diskette) (Complete all. Provide a separate electronic or print abstract.)

(a) Quantity/type (Specify)

(b) Machine compatibility (Specify)

(c) Operating system (Specify)

(d) File format SGML HTML Postscript PDF TIFFG4 Other (Specify)

(3) Audiovisual Material (Complete all. Provide a separate electronic or print abstract.)

(a) Quantity/type (Specify)

(b) Machine compatibility (Specify)
(c) Sound
Yes No

(d) Color Yes No

(e) Playing time

\section{$\checkmark$ (4) Paper}

\section{Additional Instructions/explanations}

D. Contact (Person knowledgeable about the information product and its submission)

Name Jeanne E. Sellers Position Manager, STI Phone $(803) 725-2321$

Organization Westinghouse Savannah River Company E-Mail jeanne.sellers@srs.gov 
(DOE/DOE Contractors complete; Grantees and Awardees complete as instructed by contracting officer)

A. Regommendations (Mark at least one)

1. Unlimited Announcement (Available to U.S. and non-U.S. public)

2. Unlimited Announcement/U.S. Dissemination Only

3. Classified (Standard announcement)

4. OpenNet

a. Non-NTIS Availability (Required if not available from NTIS)

(1) Accession Number

(2) Document Location

b. Field Office Acronym

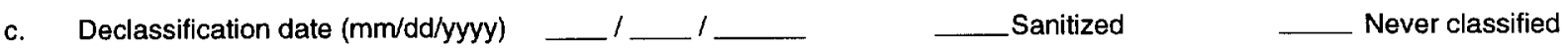

5. Special Handling (Legal basis must be noted below.)

All

Part (Specify)

b. Unclassified Controlled Nuclear Information (UCNI)

c. Export Control/ITAR/EAR

_ـ Temporary hold pending patent review

_- e. Translation of copyrighted material

f. Small Business Innovation Research (SBIP)

Release date $(m m / d d / y y y y)$ '

g. Small Business Technology Transfer (STTR)

Release date $(\mathrm{mm} / \mathrm{dd} / \mathrm{yyy} y)$

h. Proprietary

i. Protected CRADA information

Release date ( $\mathrm{mm} / \mathrm{dd} / \mathrm{yyyy})$

__. Official Use Only (OUO)

k. Program-Directed Special Handling (Specify)

I. Other (Specify)

\section{B. Releasing Official}

1. Patent Clearance (Mark one)

___ Submitted for DOE patent clearance

Date submitted (mm/dd/yyyy.

b. DOE patent clearance has been granted

c DOE patent clearance not required

2. Released by

Phone
Name

E-mail
Date $(m m d d / y y y y)$ 


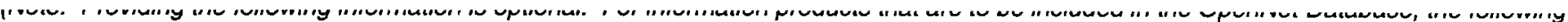
information will be used for the OpenNet Database records. For all information products, it will be used in announcing those products, as appropriate, to other parts of the DOE community.)
A. Personal Author/Affiliation
G. G. Wicks
- Westinghouse Savannah River Company

B. Performing Organization Westinghouse Savannah River

SC US

$\begin{array}{lll}\text { C. Date of Publication ( } \mathrm{mm} / d d / y y y y) & 3 / 21 / 97 & \text { D. Pages/Size_ } 11\end{array}$

\section{E. Abstract}

Significant quantities of hazardous wastes are generated from a multitude of processes and products in today's society. This waste inventory is not only very large and diverse, but is also growing at an alarming rate. In order to minimize the dangers investigated to render harmless the hazardous components and ultimately, to minimize their impact to individuals and the surrounding environment.

\section{F. Subject Terms}

G. OpenNet Document Type $\square$ Audiovisual Material $\square$ Book $\square$ Conference $\square$ Correspondance $\square$ Data $\square$ Dissertation/Thesis

\section{H. OpenNet Document Categories}

I. OpenNet Addressee 
Ms. W. F. Perrin, Technical Information Officer

U. S. Department of Energy - Savannah River Operations Office

Dear Ms. Perrin:

\section{REQUEST FOR APPROVAL TO RELEASE SCIENTIFIC/TECHINCAL INFORMATION}

The attached document is submitted for classification and technical approvals for the purpose of external release. Please complete Part II of this letter and return the letter to the undersigned by $5 / 1 / 97$ . The document has been reviewed for classification and export control by a WSRC Classification staff member and has been determined to be Unclassified

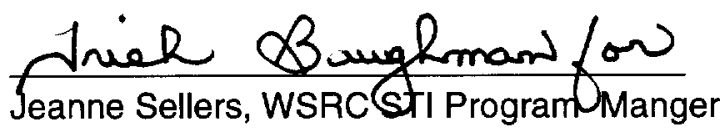

\section{DETAILS OF REQUEST FOR RELEASE}

Document Number: WSRC-MS-97-0299

Author's Name: G. G. Wicks

Location: 773-A, B-129

Phone 5-3190

Department: Focus Area Programs

Document Title: Microwave Technology for Waste Management Applications: Treatment of Discarded Electronic Circuitry (U)

Presentation/Publication:

Meeting/Journal:

Location:

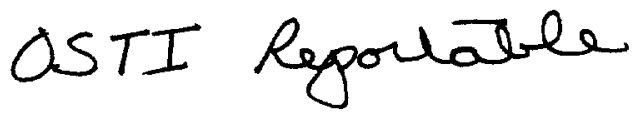

Meeting Date:

References

Q Approved for Release/Publicly Available $\square$ Included as Attachments

Routed Concurrently

$\square$ Other

II. DOE-SR ACTION

Date Received by TIO

$3 / 27 / 97$

X Approved for Release

Not Approved

$\square$ Approved Upon Completion of Changes

Approved with Remarks

Revise and Resubmit to DOE-SR

Remarks:

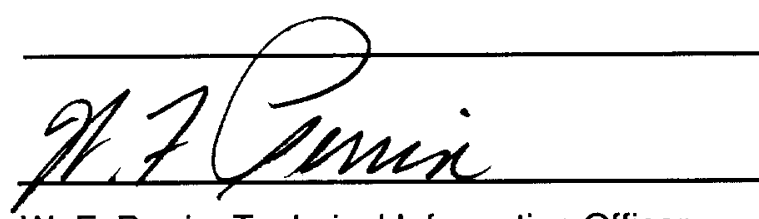

W. F. Perrin, Technical Information Officer DOE-SR

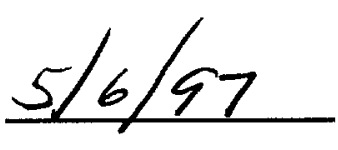

Date: 